\title{
Socio-demographic Correlates of Depression Among Elderly Slum Dwellers of
}

\section{North India}

Goel PK1, Muzammil K², Kumar S ${ }^{3}$, Singh JV', Raghav SK5

${ }^{1}$ Associate Professor, Department of Community Medicine, SHKM Govt. Medical College, Nalhar, Mewat, Haryana, India.

${ }^{2}$ Associate Professor, Department of Community Medicine, Muzaffarnagar Medical College, Muzaffarnagar, U.P, India.

${ }^{3}$ Associate Professor, Department of Community Medicine, Muzaffarnagar Medical College, Muzaffarnagar, U.P, India.

4 Professor \& Head, Department of Community Medicine, Muzaffarnagar Medical College, Muzaffarnagar, U.P, India.

${ }^{5}$ Lecture cum-statistician, Department of Community Medicine, Muzaffarnagar Medical College, Muzaffarnagar, U.P, India.

\section{Chief Editor}

Dr. Indrajit Banerjee

\section{Technical Editor}

Dr. Nishida Chandrasekharan

Formatting Editor

Dr. Indrajit Banerjee

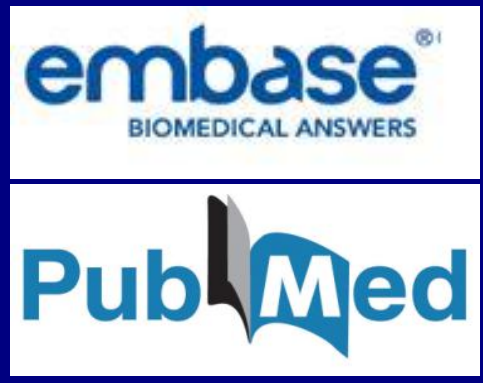

This title

is indexed

in SciVerse

Scopus

Improving research

results through

analytical power

\section{Original Article}

\section{Corresponding Author}

Dr. Pawan Kumar Goel, M.D

Associate Professor

Department of Community Medicine

SHKM Govt. Medical College

Nalhar District Mewat, Haryana, India

E-mail: drpkgoelbobby@rediffmail.com

\section{Abstract}

\section{Background}

Ageing is an inevitable process which begins before birth and continues throughout the life. Though depression is the commonest psychiatric disorder in the elderly, it is commonly misdiagnosed and under treated. The objective of the current study is to know the socio-demographic correlates of depressive disorders amongst elderly. 


\section{Socio-demographic correlates of depression}

\section{Materials and Methods}

A cross-sectional community based study was designed and conducted in an urban slum of Muzaffarnagar city, of North India, comprising of 403 elderly aged 60 years and above for a period of 6 months. First of all, the listing of elderly in the study area was done then study was started with the randomly selected name entered in list as the first one and thereafter every second elderly was interviewed alternatively with the help of predesigned proforma. The collected data was subjected to suitable statistical analysis.

\section{Results}

As the age advances the depressive disorders also increase. The prevalence of depressive disorders was found to be $9.4 \%$ and it has been observed to double with advancement of one decade of years in the age. It has been noted that there is statistically significant association between decadal age advancement and rise in number of cases of depression. No significant difference in the occurrence of depressive disorders among male and female elderly population has been found.

\section{Conclusion}

A holistic approach to underlying causes of problems of elderly should be undertaken. There is need of strengthening the existing "package" of services for elderly in various initiatives and programmes.

Keywords: Elderly, Geriatric Depression, Geriatrics

\section{Introduction}

Ageing is an inevitable process; it implies predictable progressive universal deterioration in various physical systems. Elderly population aged 60 years and above in the world is estimated to reach 1.2 billion by the year 2025, the majority of whom will be in developing countries ${ }^{1}$.

Even though depression is the commonest psychiatric disorder in the elderly, it is commonly misdiagnosed and under treated. This could be due to the misconception that depression is part of aging rather than a treatable condition. Depression decreases an individual's quality of life and increases dependence on others. If depression is left untreated, there will be significant clinical and social implications in the lives of the elderly ${ }^{2}$. Contrary to popular belief, depression is not a natural part of aging. Depression is often reversible with appropriate treatment but if left untreated, it may result in the onset of physical, cognitive and social impairment as well as delayed recovery from medical illness and surgery, increased health care utilization and suicide ${ }^{3}$.

Depression is an affective illness characterized by depressive symptoms viz. disturbance in mood, cognition and behavior; its diagnosis in elderly is often difficult. Presence of cognitive impairment as well as reluctance and denial by the elderly and their family members may make eliciting history difficult and complicate the doctor's assessment. Manifestations of depression in the elderly are also different from depression in other periods of adulthood. The elderly often present with non-specific or somatic symptoms rather than the typical symptoms of depression ${ }^{4}$.

WHO estimates that the overall prevalence rate of depression in geriatric population generally varies between 10 and $20 \%$ depending on cultural situation ${ }^{5,6}$. The proportion of elderly individual affected with depression was significantly low in Asia (4.2\%) and Europe (10.9\%) ${ }^{7}$. While Dasgupta et al reported very high prevalence (58.8\%) of depression in elderly in a rural area of India ${ }^{8}$.

There are many instruments available to measure depression, but GDS first created by Yesavage et al has been tested and used extensively with the older population is the best one. It is a brief questionnaire in which participants are asked to respond to the 30 questions by answering yes or no in reference to how they felt on the day of administration. Scores of 0-9 are considered normal; 10-19 indicate mild depression and 20-30 as severe depression ${ }^{9}$.

The validity/reliability of the GDS was found to have $92 \%$ sensitivity and $89 \%$ specificity when evaluated against diagnostic criteria ${ }^{10}$. The validity and reliability of the tool have been supported through both clinical practice and research. Strengths and limitations of GDS is that it is not a substitute for a diagnostic interview by mental health professionals. It is a useful screening tool in the clinical setting to facilitate assessment of depression in older adults especially when baseline measurements are compared to subsequent scores.

Keeping in mind that elderly are the marginalized section of our society and they face significant health problems especially depression, this study has been conducted with the objective to know the socio-demographic correlates of depressive disorders amongst elderly, so that adequate measures can be taken to strengthen the existing health and vocational services for elderly.

\section{Material and Methods}

\section{Study design and the participants:}

A cross-sectional community based study was designed and conducted in an urban slum named Khalapar of Muzaffar nagar city, of North India.

\section{Data collection:}

The study was conducted for a period of 6 months (15 June 2011 to 15 December 2011).

\section{Inclusion criteria:}

There were 856 (8.05\%) elderly residing in the area. First of all, the listing of elderly in the study area was done in the first phase then in the second phase study was started by randomly selecting a name entered in the list as the first one and thereafter every second elderly was interviewed alternatively. To cover a sample size of 423 it was planned to interview 428 individuals with the help of predesigned 


\section{Socio-demographic correlates of depression}

proforma (Hindi version of the GDS i.e., Geriatric Depression Scale) $)^{11}$.

\section{Exclusion criteria:}

Those elderly who were home bound, wheel chair bound, having non-cooperative attitude and their non-availability in the study area during the study period.

Four hundred and three elderly were studied while 25 were not covered as they fall in to exclusion category. The participants were explained regarding the purpose of the study before starting the study. Informed consent was obtained from them and confidentiality and anonymity were ensured

\section{Sample size calculation:}

To have maximum sample size for geriatric depression, assuming prevalence as $50 \%$, confidence interval $(\mathrm{Cl})$ of $95 \%$, and acceptable absolute error of $5 \%$, sample size is calculated to be 384 . Calculations are shown below:

Sample size, $\mathrm{N}=(1.96)^{2} \times \frac{\mathrm{pq}}{\mathrm{L}^{2}} \times \mathrm{D}_{\text {eff }}=3.84 \times \frac{0.5 \times 0.5}{0.05^{2}}=\sim 384$ Where,

$\mathrm{p}=$ assumed prevalence of geriatric depression

$q=1-p$

$\mathrm{L}=$ absolute error

To cover the assumed risk of non response of up to $10 \%$ among the selected study subjects, the final sample size is arrived at 423.

Sample size $(\mathrm{N})=384+38.4=422.4=423$

* Note: At any given absolute error (say $5 \%$ as in the current study), sample size is maximum for a probability of 0.5 for the positive outcome (or we can say a prevalence of $50 \%$ ). Hence to have maximum sample size for geriatric depression surveys, sample size has been calculated assuming prevalence of geriatric depression as $50 \%$.

\section{Outcome Variable:}

The main outcome variable were normal, mild depression and severe depression

\section{Explanatory variables:}

Age group, marital status, religion, caste, socio-economic class.

\section{Ethical committee approval:}

The Research was conducted in accordance to the latest version of the Declaration of Helsinki. Prior to the study, ethical committee approval was taken from the institutional ethical committee of Muzaffarnagar Medical College, Muzaffarnagar.

\section{Data management and statistical analysis:}

The collected data was recorded and subjected to suitable statistical analysis and for this Epi info statistical software package version 3.4.3 was used. To determine sociodemographic correlates of depression, univariate and multivariate regression analyses were also done. Univariate estimation was followed by derivation of different multivariate models through logistic regression with forward entry and forward step wise methods and the best multivariate derived model was selected. A two tailed $\mathrm{P}<$ 0.05 was considered statistically significant.

Result:

Out of 403 elderly studied 207 were males and 196 were females. The old-olds i.e., above 80 years of age female outnumbered male elderly study subjects (i.e., 12 and 9 respectively). The response rate of the study subjects was found to be $100 \%$. Out of these 403 subjects 38 were found to have mild and severe depression.

Table-1 shows there were 9.4\% elderly having mild (6.2\%) and severe (3.2\%) depression. It is evident that there was statistically significant $(p<0.001)$ association between decadal age advancement and rise in number of cases of depression.

Table-1: Distribution of study subjects with \& without depression by age

\begin{tabular}{|c|c|c|c|c|c|c|c|c|}
\hline \multirow{3}{*}{$\begin{array}{l}\text { Geriatric } \\
\text { Depression } \\
\text { Scale (GDS) }\end{array}$} & \multicolumn{6}{|c|}{ AGE GROUP } & & \\
\hline & \multicolumn{2}{|c|}{$\begin{array}{c}60-70 \text { yrs } \\
(n=309)\end{array}$} & \multicolumn{2}{|c|}{$\begin{array}{c}70-80 \text { yrs } \\
(n=73)\end{array}$} & \multicolumn{2}{|c|}{$\begin{array}{l}>80 y r s \\
(n=21)\end{array}$} & \multicolumn{2}{|c|}{$\begin{array}{l}\text { TOTAL } \\
(\mathrm{N}=403)\end{array}$} \\
\hline & No. & $\%$ & No. & $\%$ & No. & $\%$ & No. & $\%$ \\
\hline $\begin{array}{c}\text { Normal } \\
0-9\end{array}$ & 288 & (93.2) & 63 & (86.3) & 14 & (66.7) & 365 & (90.6) \\
\hline $\begin{array}{l}\text { Mild depression } \\
10-19\end{array}$ & 14 & (4.5) & 06 & (8.2) & 05 & (23.8) & 25 & (6.2) \\
\hline $\begin{array}{c}\text { Severe } \\
\text { depression } \\
20-30\end{array}$ & 07 & (2.3) & 04 & (5.5) & 02 & (9.5) & 13 & (3.2) \\
\hline TOTAL & 309 & (100) & 73 & (100) & 21 & (100) & 403 & (100) \\
\hline Chi-square test & & & & $<0.001$ & $; d f=$ & & & \\
\hline
\end{tabular}

Table-2 depicts that there is no significant difference in the occurrence of depressive disorders among male and female elderly population.

Table-3 demonstrates that there is no significant relationship of socio-demographic correlates in the causation of depressive disorders among the study subjects except decadal age group advancement. However, those not living with spouse, unemployed and elderly belonging to low socio-economic class have higher prevalence of depression. 


\section{Socio-demographic correlates of depression}

Table-2: Distribution of study subjects with \& without depression by Gender.

\begin{tabular}{|c|c|c|c|c|c|c|}
\hline \multirow{3}{*}{$\begin{array}{c}\text { Geriatric } \\
\text { Depression } \\
\text { Scale (GDS) }\end{array}$} & \multicolumn{4}{|c|}{ SEX } & \multirow{2}{*}{\multicolumn{2}{|c|}{$\begin{array}{c}\text { TOTAL } \\
\text { (N=403) }\end{array}$}} \\
\hline & \multicolumn{2}{|c|}{ Male $(n=207)$} & \multicolumn{2}{|c|}{ Female $(n=196)$} & & \\
\hline & No. & $\%$ & No. & $\%$ & No. & $\%$ \\
\hline $\begin{array}{c}\text { Normal } \\
0-9\end{array}$ & 187 & (90.3) & 178 & (90.8) & 365 & (90.6) \\
\hline $\begin{array}{l}\text { Mild depression } \\
10-19\end{array}$ & 13 & (6.3) & 12 & (6.1) & 25 & (6.2) \\
\hline $\begin{array}{c}\text { Severe depression } \\
20-30\end{array}$ & 07 & (3.4) & 06 & (3.1) & 13 & (3.2) \\
\hline TOTAL & 207 & $(100)$ & 196 & (100) & 403 & (100) \\
\hline Chi-square test & & & $p>$ & $15 ; d f=$ & & \\
\hline
\end{tabular}

Table-3: Distribution of subjects with depression by Sociodemographic correlates.

\begin{tabular}{|c|c|c|c|c|c|c|c|}
\hline \multirow[b]{2}{*}{ SI. No. } & \multirow{2}{*}{\multicolumn{2}{|c|}{$\begin{array}{l}\text { Socio-demographic } \\
\text { correlates (No.) }\end{array}$}} & \multicolumn{4}{|c|}{ Depression No depression } & \multirow[b]{2}{*}{ p - value } \\
\hline & & & No. & (\%) & No. & (\%) & \\
\hline \multirow{3}{*}{1} & \multirow{3}{*}{ Age group } & $\begin{array}{l}60-70 \\
(309)\end{array}$ & 21 & $(06.8)$ & 288 & (93.2) & \multirow{3}{*}{$p<0.001$} \\
\hline & & $\begin{array}{l}70-80 \\
(73)\end{array}$ & 10 & (13.7) & 63 & (86.3) & \\
\hline & & $\begin{array}{l}>80 \\
(21)\end{array}$ & 07 & (33.3) & 14 & $(66.7)$ & \\
\hline \multirow{2}{*}{2} & \multirow{2}{*}{ Sex } & $\begin{array}{l}\text { Male } \\
(207)\end{array}$ & 20 & (09.6) & 187 & (90.3) & \multirow{2}{*}{$p>0.05$} \\
\hline & & $\begin{array}{l}\text { Female } \\
\text { (196) }\end{array}$ & 18 & (09.2) & 178 & $(90.8)$ & \\
\hline \multirow[b]{2}{*}{3} & \multirow[b]{2}{*}{$\begin{array}{l}\text { Marital } \\
\text { status }\end{array}$} & $\begin{array}{l}\text { Married } \\
\text { (192) }\end{array}$ & 17 & (8.8) & 175 & (91.2) & \multirow[b]{2}{*}{$p>0.05$} \\
\hline & & $\begin{array}{l}\text { Widow/ } \\
\text { widower/ } \\
\text { Living alone } \\
\text { (211) }\end{array}$ & 30 & (14.2) & 181 & (85.8) & \\
\hline \multirow{2}{*}{4} & \multirow{2}{*}{ Occupation } & $\begin{array}{l}\text { Working } \\
\text { (95) }\end{array}$ & 08 & (8.4) & 87 & (91.6) & \multirow{2}{*}{$p>0.05$} \\
\hline & & $\begin{array}{l}\text { Not Working } \\
\text { (308) }\end{array}$ & 39 & (12.7) & 269 & (87.3) & \\
\hline \multirow{4}{*}{5} & \multirow{4}{*}{ Religion } & $\begin{array}{l}\text { Hindu } \\
\text { (27) }\end{array}$ & 03 & (11.1) & 24 & (88.9) & \multirow{4}{*}{$p>0.05$} \\
\hline & & $\begin{array}{l}\text { Muslims } \\
\text { (371) }\end{array}$ & 43 & (11.6) & 328 & (88.4) & \\
\hline & & $\begin{array}{l}\text { Sikhs } \\
\text { (3) }\end{array}$ & 01 & (33.3) & 02 & (66.7) & \\
\hline & & $\begin{array}{l}\text { Christian } \\
\text { (2) }\end{array}$ & - & $(-)$ & 02 & (100.0) & \\
\hline \multirow{3}{*}{6} & \multirow{3}{*}{ Caste } & $\begin{array}{c}\text { General } \\
(170)\end{array}$ & 24 & (14.1) & 146 & (85.9) & \multirow{3}{*}{$p>0.05$} \\
\hline & & $\begin{array}{l}\mathrm{OBC} \\
(210)\end{array}$ & 19 & (9.1) & 191 & (90.9) & \\
\hline & & $\begin{array}{l}\text { SC } \\
(23)\end{array}$ & 04 & (17.4) & 19 & (82.6) & \\
\hline \multirow{5}{*}{7} & \multirow{5}{*}{ SEX } & $\begin{array}{c}1 \\
(2)\end{array}$ & - & $(-)$ & 02 & $(100.0)$ & \multirow{5}{*}{$p>0.05$} \\
\hline & & $\begin{array}{c}\text { II } \\
(35)\end{array}$ & 02 & (5.7) & 33 & (94.3) & \\
\hline & & $\begin{array}{c}\text { III } \\
(116)\end{array}$ & 09 & (7.8) & 107 & (92.2) & \\
\hline & & $\begin{array}{l}\text { IV } \\
(147)\end{array}$ & 18 & (12.2) & 129 & (87.8) & \\
\hline & & $\begin{array}{c}\mathrm{V} \\
(103)\end{array}$ & 18 & (17.5) & 85 & (82.5) & \\
\hline
\end{tabular}

Table 4 revealed that in univariate analysis of sociodemographic correlates of depression increasing age was associated with increasing risk of depression $(P=0.0001$ for age $>80$ years). Socio-economic status class $V$ was also associated with increasing risk of depression $(P=0.033)$. On multiple logistic regression, age $>80$ years, Widow/widower/Living alone, $\mathrm{OBC}$ caste and Socioeconomic status class $\mathrm{V}$ were also found associated with increasing risk of depression significantly.

\section{Discussion:}

\section{Prevalence of depression:}

Countries across the world are experiencing an ageing population phenomenon. The proportion (8.05\%) of elderly population in the current study has found to be comparable to the national estimates of $8.14 \%$ for the year of 2011 . It is projected that the population of older adults in the world will rise by $21 \%$ in the next 50 years and by the year 2050 there will be an expected quadruple increase in the elderly population to almost two billion in the developing countries $^{12}$. Although mental health is important to the elderly, only a fraction of those who need mental health care receive it. By one estimate only about $10 \%$ of older adults who are in need of psychiatric treatment ever receive this service ${ }^{13}$. Prevalence of depression in the Asia- Pacific region is comparable to that of the Western world ${ }^{14}$. Depression is associated with morbidity as well as disability among the elderly. They constitute a major public health problem worldwide and their prevalence rates range between 10 and 55\%. Jain and Aras (2007) conducted a study which is the only available Indian study employing the Geriatric Depression Scale (GDS) as screening tool in a small sample of elderly reported the prevalence of up to $45.9 \%$. The prevalence of depression in this study population (9.4\%) has found to be comparable to the WHO estimates of depression in geriatric population between 10 and $20 \%$ depending on cultural situation ${ }^{5,6}$. Mental health studies in India have revealed that the point prevalence of depression in geriatric population varies between $13 \%$ and $25 \%{ }^{15,16}$. In a retrospective study it has been reported that the median prevalence rate of depressive disorders in the world for the elderly population from the 74 studies was determined to be $10.3 \%$ with a \pm QR varying between $4.7 \%$ and $16.0 \%{ }^{7}$. Almost similar findings have also been reported by Kirby et al and Kay et $\mathrm{al}^{17,18}$. Studies conducted by Geerlings et al, Newman et al and Liu et al, also reported the prevalence rate of depression among the elderly to be $10.5 \%, 11.2 \%$, and $12.9 \%$, respectively ${ }^{19-21}$. These findings are almost in consistent with our findings where prevalence of depression among elderly has been reported to be $9.4 \%$. The comparison of the median prevalence rates of depression in the elderly population of India and the rest of the world was also studied and it was found that the proportion of the depressed elderly population in India (18.2\%) was significantly higher than the rest of the world $(5.4 \%)$ and this difference was found to be statistically highly significant $(p<0.001)$. 
Table 4: Socio-demographic correlates of depression.

\begin{tabular}{|c|c|c|c|c|c|c|}
\hline \multirow{2}{*}{ Predictor variables } & \multirow{2}{*}{$\begin{array}{l}\text { Depression (\%) } \\
\text { No. (\% of } n)\end{array}$} & \multirow{2}{*}{$\begin{array}{c}\begin{array}{c}\text { No depression } \\
(\%)\end{array} \\
\text { No. (\% of } n)\end{array}$} & \multicolumn{2}{|c|}{ Univariate analysis } & \multicolumn{2}{|c|}{ Multivariate analysis } \\
\hline & & & OR $(95 \% \mathrm{Cl})$ & p-value & OR $(95 \% \mathrm{Cl})$ & p-value \\
\hline \multicolumn{7}{|c|}{ Age group } \\
\hline $60-70$ (309) & $21(06.8)$ & 288 (93.2) & 1 & - & 1 & - \\
\hline $70-80(73)$ & 10(13.7) & $63(86.3)$ & $\begin{array}{c}3.810 \\
(1.492-8.615)\end{array}$ & $0.167 x$ & $\begin{array}{c}1.892 \\
(0.632-4.405)\end{array}$ & $0.08^{\dagger}$ \\
\hline$>80(21)$ & $07(33.3)$ & $14(66.7)$ & $\begin{array}{c}5.692 \\
(2.994-19.607)\end{array}$ & $0.0001 \dagger$ & $\begin{array}{c}3.446 \\
(1.222-10.304)\end{array}$ & $0.032 \dagger$ \\
\hline \multicolumn{7}{|c|}{ Gender } \\
\hline Male (207) & $20(09.6)$ & $187(90.3)$ & 1 & - & 1 & \multirow[b]{2}{*}{$0.517 x$} \\
\hline Female (196) & $18(09.2)$ & $178(90.8)$ & $\begin{array}{c}1.950 \\
(0.517-1.704)\end{array}$ & $0.865 x$ & $\begin{array}{c}0.950 \\
(0.427-1.109)\end{array}$ & \\
\hline \multicolumn{7}{|c|}{ Marital status } \\
\hline Married (192) & $17(8.8)$ & 175(91.2) & 1 & - & 1 & - \\
\hline $\begin{array}{l}\text { Widow/ widower/ } \\
\text { Living alone (211) }\end{array}$ & $30(14.2)$ & $181(85.8)$ & $\begin{array}{c}2.281 \\
(0.943-5.151)\end{array}$ & $0.093 x$ & $\begin{array}{c}2.151 \\
(0.783-5.154)\end{array}$ & $0.05{ }^{\dagger}$ \\
\hline \multicolumn{7}{|c|}{ Occupation } \\
\hline Working (95) & $08(8.4)$ & 87 (91.6) & 1 & - & 1 & \multirow[b]{2}{*}{$0.284 x$} \\
\hline Not Working (308) & 39(12.7) & $269(87.3)$ & $\begin{array}{c}2.251 \\
(0.983-5.154)\end{array}$ & $0.26 x$ & $\begin{array}{c}2.251 \\
(0.983-5.154)\end{array}$ & \\
\hline \multicolumn{7}{|c|}{ Religion } \\
\hline Hindu (27) & $03(11.1)$ & 24 (88.9) & 1 & - & 1 & - \\
\hline Muslims (371) & 43 (11.6) & $328(88.4)$ & $\begin{array}{c}2.559 \\
(0.187-12.987)\end{array}$ & $0.778 x$ & $\begin{array}{c}3.767 \\
(2.542-9.007)\end{array}$ & $0.275 x$ \\
\hline Sikhs (3) & $01(33.3)$ & $02(66.7)$ & $\begin{array}{c}3.745 \\
(0.449-31.25)\end{array}$ & $0.315 x$ & $\begin{array}{c}4.756 \\
(2.532-8.421)\end{array}$ & $0.584 x$ \\
\hline Christian (2) & - & $02(100.0)$ & $\begin{array}{c}2.829 \\
(0.477-14.429)\end{array}$ & NA & $\begin{array}{c}3.195 \\
(2.514-6.254)\end{array}$ & - \\
\hline \multicolumn{7}{|c|}{ Caste } \\
\hline General (170) & $24(14.1)$ & $146(85.9)$ & 1 & - & 1 & - \\
\hline OBC (210) & 19(9.1) & 191(90.9) & $\begin{array}{c}3.147 \\
(2.264-7.258)\end{array}$ & $0.08^{\dagger}$ & $\begin{array}{c}3.614 \\
(1.348-9.709)\end{array}$ & $0.05^{\dagger}$ \\
\hline SC (23) & 04 (17.4) & 19 (82.6) & $\begin{array}{c}4.462 \\
(2.542-9.451)\end{array}$ & $0.237 x$ & $\begin{array}{c}2.267 \\
(2.754-6.224)\end{array}$ & $0.227 x$ \\
\hline \multicolumn{7}{|c|}{ Socio-economic Status } \\
\hline I (2) & - & $02(100.0)$ & 1 & - & 1 & \\
\hline II (35) & $02(5.7)$ & $33(94.3)$ & $\begin{array}{c}2.141 \\
(0.824-5.347)\end{array}$ & $0.405 x$ & $\begin{array}{c}3.891 \\
(1.941-7.985)\end{array}$ & $0.273 x$ \\
\hline III (116) & $09(7.8)$ & 107(92.2) & $\begin{array}{c}2.212 \\
(0.831-6.256)\end{array}$ & $0.12 x$ & $\begin{array}{c}1.863 \\
(0.362-4.356)\end{array}$ & $0.09 \dagger$ \\
\hline IV (147) & $18(12.2)$ & $129(87.8)$ & $\begin{array}{c}3.861 \\
(1.922-7.921)\end{array}$ & $0.782 x$ & $\begin{array}{c}2.251 \\
(0.283-5.147)\end{array}$ & $0.311 \times$ \\
\hline$V(103)$ & 18 (17.5) & $85(82.5)$ & $\begin{array}{c}3.644 \\
(1.396-9.732)\end{array}$ & $0.033^{\dagger}$ & $\begin{array}{c}4.766 \\
(2.532-9.041)\end{array}$ & $0.047 \dagger$ \\
\hline & $+p<0.0$ & dence interval, OF & dds ratio, NA-Not & licable & & \\
\hline
\end{tabular}




\section{Socio-demographic correlates of depression}

As there has been graying of population in recent years, we need to consider the number of depressed elderly individuals who would require adequate mental health care. An alarming eight-fold increase was recorded from the period 1955-1984 to 1995-2005 in the number of elderly suffering from depression and this trend was found to be statistically significant ${ }^{7}$. Banerjee I, reported females patients $(55.3 \%)$ were having higher prevalence of depression in comparison to male patients $44.7 \%$ in a tertiary care hospital in contrary to present study reporting lower prevalence in female $9.2 \%$ than male $9.7 \%$ study subjects $^{22}$.

\section{Socio-demographic correlates and depression:}

In some studies it was revealed that marriage has been shown to be a protective factor against depression in the elderly $^{23,8}$. The findings of this study are similar to other studies conducted in health clinics in Malaysia ${ }^{24}$. In a study conducted in 2005 it was revealed that family members who care for their elderly have been found to be a protective factor against depression. It also showed higher risks of depression among unmarried older adults ${ }^{25}$. It is assumed that married people are exposed to lesser stressful experiences throughout their married life and thus decrease the risk of being depressed. Another reason for this could be that unmarried older adults may feel loneliness because of the lack of companionship. Being lonely is a risk factor for depression. Older adults who live alone or in residential homes are susceptible to loneliness ${ }^{26}$. Findings of this study along with other studies conducted in Malaysia have shown low social support as a risk factor for depression ${ }^{27}$. All these findings are almost in consistent with the findings of the current study.

\section{Conclusion}

It is concluded that a holistic approach to underlying causes of depression amongst elderly should be undertaken. There is need of strengthening the existing "package" of services for elderly under various initiatives and programs by means of IEC (Information Education \& Communication) and BCC (Behavioural Change Communication) especially to bring a social change targeting towards the elderly.

\section{Limitation of the study}

The geriatric depression scale is a tool used for screening purposes hence there is a need for further clinical examination and investigation of those elderly who had mild or severe depression.

\section{Relevance of the study:}

The study can provide baseline data for researchers for further investigation.

\section{Future scope of the study:}

A larger national level study is required to be conducted for detailed data collection.

\section{Author's Contribution:}

PKG designed the study, collected the data and drafted manuscript. KM helped in designing the study and revision

of the manuscript. SK assisted in manuscript write up. JVS critically revised the manuscript. SKR helped in data analysis and interpretation. All the authors approved the final document.

\section{List of Abbreviations}

GDS $=$ Geriatric depression scale

$\mathrm{MSW}=$ Medico-social worker

$\mathrm{OBC}=$ Other backward caste

SES $=$ Socio-economic Status

$\mathrm{SC}=$ Schedule caste

UHTC $=$ Urban Health Training Center

WHO $=$ World Health Organization

\section{Acknowledgements:}

We sincerely thank the Lady Medical Officer and the Medical Social Worker of Urban Health Training Center, Khalapar, Muzaffarnagar for all of their valuable help, support and cooperation.

\section{Conflict of interest:}

None

\section{References:}

1. Arokiasamy JT. Malaysia's Ageing Issues (Editorial). Med J Malaysia 1997; 52: 197-201.

PMid:10968084

2. Blanchard MR, Waterraus A, Mann AH. The nature of depression among older people in inner London and the contact with primary care. British Journal of Psychiatry 1994; 164: p. 396-402.

http://dx.doi.org/10.1192/bjp.164.3.396

PMid:8199793

3. Lenore K. The Geriatric Depression Scale (GDS). Try this: best practices in nursing care to older adults: The Hartford institute for geriatric nursing. (online) 1999 [cited 2014 Jan 31]. Available from: URL:http://wiki.ihe.net/images/1 /1c/Geriatric_Depression_Scale.pdf

4. VanDerPol CA, Setter SM, Hunter KA et al. Depression in community dwelling elders. Postgrad.Med 1998; 103(3): p. 165-67

PMid:9519036

5. Rangaswamy SM, editor. World Health Organization (2001). The World Health Report 2001- Mental Health: New understanding New Hope. Geneva, World Health Organization.

6. Wig NN. World Health Day, 2001. Indian J Psychiatry. 2001;43: 1-4.

PMid:21407829 PMCid:PMC2955923

7. Barua A, Ghosh MK, Kar N, Basilio MA. Prevalence of depressive disorders in the elderly. Ann Saudi Med.

2011Nov-Dec; 31(6): 620-24.

http://dx.doi.org/10.4103/0256-4947.87100

PMid:22048509 PMCid:PMC3221135

8. Dasgupta A, Ray D, Roy S, Sarkar T, Ghoshal A, Das A, Pal J. Depression among the geriatric population is a matter of concern: A community based study in a rural area of West 


\section{Socio-demographic correlates of depression}

Bengal. Nepal journal of epidemiology 2013; 3 (4): 282-287 http://dx.doi.org/10.3126/nje.v3i4.9515

9. Yesavage JA, Brink TL, Rose TL et al. Development and validation of a geriatric depression rating scale: a preliminary report. J Psych Res 1983; 17: p. 27.

10. Koenig HG, Meador KG, Cohen HJ, Blazer DG. Self-rated depression scales and screening for major depression in the older hospitalized patient. J Am GeriatrSoc 1998; 36(8): p. 699-706

11. University of Pittsburgh, Graduate School of Public Health, Department of Epidemiology \& School of Medicine, Department of Psychiatry, Pittsburgh, Pennsylvania, USA and Centre for Ageing Research, India, with the cooperation of the Centre for Community Medicine, All India Institute of Medical Sciences, New Delhi, India. INDO US cross-national dementia epidemiology study. Geriatric depression scale - hindi version (GDS-H). Western Psychiatric Institute \& Clinic, UPMC Health System, School of Medicine, University of Pittsburgh website. Available at: http://www.stanford.edu/ yesavage/Hindi.html. (Cited Dec 14, 2011)

12. Consensus Development Statement. Diagnosis andtreatment of depression in late life. National Institute of Health [online] 1991 [cited 2014 Jan 25]. Available from:URL: http://www.mentalhealth.com

13. Consensus Development Statement. Diagnosis and treatment of depression in late life. National Institute of Health; $1991 . \quad$ Available at http:/www.mentalhealth.com/book/pus-dpo1htm. Last accessed on 14.12.11

14. Chiu E. Epidemiology of depression in Asia Pacific Region. Reducing the social and economic burdens of depression in Asia. Australasian Psychiatry 2004;12(2): p. 24-210

15. Nandi DN, Ajmany S, Ganguli H, Banerjee G, Boral GC, Ghosh $A$. The Incidence of mental disorders in one year in a rural community in West Bengal. Indian J Psychiatry. 1976;18: p. 79-87

16. Ramachandran V, MenonSarada M, Arunagiri S. Sociocultural factors in late onset Depression. Indian J sychiatry. 1982;24: p. 268-73

PMid:21965922 PMCid:PMC3012816

17. Aisling D, Kirby M, Bruce I, Cunningham C, Coakley D, Lawlor BA. Three-year prognosis of Depression in the community-dwelling elderly. Br J Psychiatry. 2000;176: p. 453-7

http://dx.doi.org/10.1192/bjp.176.5.453

18. Kay DW, Henderson AS, Scott R, Wilson J, Rickwood D, Grayson DA. Dementia and depression among the elderly living in the Hobart community: The effect of the diagnostic criteria on the prevalence rates. Psychol Med. 1985;15: p. 771-88.

http://dx.doi.org/10.1017/S0033291700005006

PMid:4080881

19. Schoevers RA, Geerlings MI, Beekman AT, Penninx BW,
Deeg DJ, Jonker C, et al. Association of Depression and gender with mortality in old age. Br J Psychiatry. 2000;177: p. 336-42.

http://dx.doi.org/10.1192/bjp.177.4.336

PMid:11116775

20. Newman SC, Bland RC, Orn HT. The prevalence of mental disorders in the elderly in Edmonton: A community survey using GMS-AGECAT. Can J Psychiatry. 1998;43: p. 910-4

PMid:9825162

21. Liu CY, Wang SJ, Teng EL, Fuh JL, Lin CC, Lin KN, Chen $\mathrm{HM}$, Lin CH, Wang PN, Yang YY, Larson EB, Chou P, Liu HC. Depressive disorders among older residents in a Chinese rural community. Psychol Med. 1997 Jul;27(4):943-9 http://dx.doi.org/10.1017/S0033291797005230 PMid:9234471

22. Banerjee I, Roy B, Banerjee I, Sathian B, Mondol M, Saha A. Depression and its cure: A drug utilization study from a tertiary care center of Western Nepal. Nepal Journal of Epidemiology 2011; 1 (5): 144-52. http://dx.doi.org/10.3126/nje.v1i5.6152

23. Chen RL, Hu Z, Wei L, Qin X, McCracken C, Copeland JR. Severity of depression and risk for subsequent dementia: cohort studies in China and the UK. Br J Psychiatry 2008;193(5): p. 373-377.

http://dx.doi.org/10.1192/bjp.bp.107.044974 PMid:18978315

24. Sherina MS, Afiah N, Zulkefli M, Shah SA. Factor associated with depression among elderly patients in a primary health care clinic in Malaysia. Asia Pac Fam Med 2003;2: p. 148-152.

http://dx.doi.org/10.1046/j.1444-1683.2003.00080.x

25. Winrow AM, Holmes JD. Old age medical patients screening positive for depression. Ir J Psychol Med 2005;22(4): p. 124-27

26. Savikko N. Rautaalo P. Tilvis R. Strandberg T. Pitkala K. Predictors and subjective courses of loneliness in an aged population. Arch GerontolGeriatr 2005;41(3): p. 223-233 http://dx.doi.org/10.1016/j.archger.2005.03.002 PMid:15908025

27. Izzuna NMG, Ayu MS. Myint MS, Bakar A. Social support and depression among elderly Malays in a rural community in Malaysia. J Community Health 2006; Supplement 2006: p. 37

\begin{tabular}{|l|c|}
\hline \multicolumn{2}{|c|}{ Article Information } \\
\hline \multicolumn{2}{|c|}{ Article history } \\
\hline Received & $2^{\text {nd }}$ February 2014 \\
Received in revised form & $18^{\text {th }}$ March2014 \\
Accepted & $23^{\text {rd }}$ March 2014 \\
\hline
\end{tabular}

